\section{Microbiological Assay of Indole in Cultures of Escherichia coli and Some Other Microorganisms}

The assay of indole as a fission product of the enzyme tryptophanase causes no special difficulties in routine diagnosis of Escherichia coli and other microorganisms. The most common method is the assay by means of a $p$ dimethylamino-benzaldehyde reagent ${ }^{1,2}$; other methods are Gnezda's test employing oxalic acid ${ }^{3}$, Salkowski's nitrose-indole reaction ${ }^{4}$, and perhaps the test with vanilines. All the reactions mentioned are, however, not specific only for indole; scatole, other indole derivatives and a number of other compounds show a similar reaction.

37 years ago, GraY ${ }^{6}$ was able to isolate from soil an interesting microorganism, Pseudomonas indoloxydans, which specifically oxidized indole to a blue staining substance: indigotine. The above microorganism was used by the authors for an assay of indole production from tryptophane in $E$. coli on a solid medium. Composition of medium: yeast extract, $3 \mathrm{~g}$; $d l$-tryptophane, $5 \mathrm{~g}$; disodiumphosphate, $1 \mathrm{~g}$; sodium chloride, $5 \mathrm{~g}$; agar, $12 \mathrm{~g}$; distilled water, $1000 \mathrm{ml}$. Agar slants were made in small tubes $(0.8 \cdot 8 \mathrm{~cm}), 1-1.5 \mathrm{ml}$ agar in each, and the surface was massively inoculated with the microorganism under investigation ( $E$. coli $)$. On the surface of the medium thus inoculated, a thick layer of $P$. indoloxydans $(48 \mathrm{~h}$ culture on agar slant, cultivated at $25-28^{\circ} \mathrm{C}$ ) was streaked with a loop in the direction of the long axis, in the form of a line approximately $1 \mathrm{~cm}$ long and $0.2 \mathrm{~cm}$ wide. Following $24 \mathrm{~h}$ incubation at $25-28^{\circ} \mathrm{C}$, indole production was manifested in a more or less intense blue colouration of the site and the neighbourhood inoculated with $P$. indoloxydans. The reaction proceeds according to the following scheme:

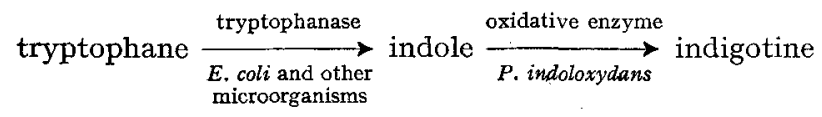

The production of indigotine from indole by $P$. indolo $x y$ dans is very sensitive and specific for indole. Scatole, isatine, indolacetic acid tryptophane and other indole derivatives fail to react. With $E$. coli, the reaction was absolutely reliable and agreed in all cases with the routine assay of indole by means of the chemical reaction with the $p$-dimethylaminobenzaldehyde reagent. A total of 172 microorganisms, including $109 \mathrm{E}$. coli strains, have so far been examined in this way. Of the other indole-positive microorganisms, only the following members of Enterobacteriaceae have hitherto been examined: Shigella flexneri, Klebsiella oxytocum, and the group Proteus-Providencia. The reaction proved to be unreliable only in the group Proteus-Providencia, probably in view of the fact that on the medium we have used, rich in tryptophane, bacteria of the Proteus-Providencia group produce a specific reddish-brown pigment 7 , the production of which probably interferes with the reaction of indigotine formation by $P$. indoloxydans.

It is our opinion that the microbiological assay of indole by means of $P$. indoloxydans can be used with $E$. coli and some other microorganisms as a simple and specific diagnostic method. As has already been shown by some preexperiments, it may be possible to utilize this method for a specific and highly sensitive assay of indole, also in other biological material.

Zusammenfassung. Methode zur Indolbestimmung in Kulturen von Escherichia coli und manchen anderen Mikroorganismen mit Hilfe des Pseudomonas indoloxydans. Diese Bakterien oxydieren spezifisch Indol zum blauen Farbstoff Indigotin. Die Methode ist auch für Indolbestimmung in anderem biologischem Material optimal geeignet.

M. POLSTER

Institute of Hygiene and Epidemiology, Faculty of

Medicine, University J. E. Purkynę, Brno

(Czechoslovakia), December 23, 1965.

1 Manual of Microbiological Methods (McGraw.Hill Book Co., 1957).

2 N. Kovacz, Z. ImmunForsch. exp. Ther. 55, 311 (1928).

3 W. L. Holman and L. Gonzales, J. Bact. 8, 577 (1923).

4 H. F. Zoller, J. biol. Chem. 41, 25 (1920).

5 C. R. Fellers and R. W. Glough, J. Bact. 10, 105 (1925).

P. H. M. Gray, Proc. R. Soc. Ser. B 102, 263 (1928).

7 M. Polster and M. Svobodová, Experientia 20, 637 (1964).

\section{Chlorpromazine and Fur Shaking in Mice}

As a multi-response approach, the construction of ethograms has found application in psychogenetics ${ }^{1}$ as well as in psychopharmacology ${ }^{2}$. In the framework of a study $^{3}$ on the relations between behavioral variables, gene action, and drug action, the effects of chlorpromazine on stereotyped behavioral components displayed by mice from four different strains were examined. The present report focuses on a specific effect of a moderate dose of the drug on behavior.

Experimental. The subjects used were 20 male mice aged $21 / 2$ months from each of the following strains: $\mathrm{DBA} / 2 \mathrm{~J}, \mathrm{C} 57 \mathrm{BL} / 6 \mathrm{~J}, \mathrm{~B} 6 \mathrm{D} 2 \mathrm{~F}_{1}, \mathrm{SEC} / 1 \mathrm{Gn}$ (se se mice), and $\mathrm{SEC} / 1 \mathrm{Gn}$ (se + mice). In each group, one half of the animals received chlorpromazine in isotonic saline $\mathbf{1 0 . 9 5}$ $\mathrm{mg} / \mathrm{kg}$ of body weight; total volume approximately 0.17 $\mathrm{ml}$ ), injected intraperitoneally $1 \mathrm{~h}$ before testing; the controls received saline. Earlier observations indicated that administering the drug in double or quadruple doses induced drowsiness and dragging with the hind legs, thus resulting in a general suppression of locomotor activity.

Frequency counts were made of 34 acts and postures exhibited by the mice when placed singly for $20 \mathrm{~min}$ and in pairs for $15 \mathrm{~min}$ in a large observation cage. Simultaneously, locomotor activity was recorded by means of

1 J. H. F, van Abeelen, Genetica 34, 79 (1963).

2 A. P. Silverman, Br. J. Pharmacol. Chemother. 24, 579 (1965).

3 J. H. F. van Abeelen, Anim. Behav. 14 (1966).

4. J. StaAts, Cancer Res. 24, 147 (1964). 